Prophetic: Professional, Empathy and Islamic Counseling Journal

Vol. 2, No. 2, Desember 2019, hlm. 177-188

e-ISSN : 2685-0702, p-ISSN : 2654-3958

Tersedia Online di http://syekhnurjati.ac.id/jurnal/index.php/prophetic

Email: prophetic@syekhnurjati.ac.id

\title{
Keluarga, Teman Sebaya dan Perilaku Seksual Remaja
}

\author{
Suci Nofita Sari \\ Program Studi Kesehatan Masyarakat, STIKes Kharisma Persada \\ sucinofitasari@gmail.com
}

\begin{abstract}
Abstrak
Remaja merupakan masa transisi dengan berbagai permasalahan yang sangat kompleks. Salah satu masalah yang menonjol dikalangan remaja terkait perilaku seksual. Tujuan penelitian ini untuk melihat hubungan teman sebaya serta keluarga dan perilaku seksual remaja. Disain penelitian menggunakan metode cross sectional dengan jumlah sampel 124 orang. Hasil penelitian menunjukkan 66,1\% mahasiswa memiliki perilaku seksual berisiko dan pengaruh teman sebaya besar sebesar 49,2\%. Sebagian besar remaja memperoleh dukungan keluarga besar $(60,5 \%)$ dan sebagian besar tidak melakukan komunikasi $(75,8 \%)$. Hasil uji hipotesis diperoleh remaja dengan pengaruh negatif teman sebaya yang besar lebih banyak melakukan perilaku seksual berisiko (70,5\%) dibandingkan dengan pengaruh kecil $(36,5 \%)$ dengan nilai PR 4,2 dimana remaja dengan pengaruh teman sebaya yang besar berisiko melakukan perilaku sesksual sebesar 4,2 kali.
\end{abstract}

Kata Kunci: Keluarga; Teman Sebaya; Perilaku Seksual Remaja.

\section{PENDAHULUAN}

Remaja merupakan masa peralihan dari masa kanak-kanak ke masa dewasa yang mencakup perubahan biologis, perubahan kognitif dan perubahan sosial-emosional (Santrock, 2003). Data Badan Pusat Statistik (BPS RI) (2010), menunjukkan jumlah remaja umur 15-24 tahun di Indonesia sekitar 40 juta $(19,61 \%)$ dari jumlah penduduk. Selain jumlahnya yang besar, remaja juga mempunyai permasalahan yang sangat kompleks seiring dengan masa transisi yang dialaminya. Begitu banyak perubahan yang dirasakan remaja sehingga dapat membuat perasaan tidak nyaman. Kondisi ini yang menyebabkan remaja dalam kondisi yang rawan dalam menjalani proses pertumbuhan dan perkembangannya. Sifat remaja yang selalu ingin mencoba hal-hal baru dapat menjadi faktor resiko karena dapat membawa akibat yang sangat buruk dan merugikan masa depan remaja. Berbagai permasalahan yang biasa dialami remaja menjadi 8 kelompok, yaitu gangguan gizi, peningkatan penyalahgunaan NAPZA, Infeksi Seksual Seksual (IMS) termasuk HIV/AIDS, kehamilan remaja, kehamilan yang tidak diinginkan (KTD) dan abortus, kecelakaan, kenakalan remaja, kekerasan terhadap perempuan (KTP) dan 
kesehatan mental serta seksual eksploitasi di tempat kerja, khususnya pekerja anak (Joshi, 2011). Masalah yang menonjol dikalangan remaja salah satunya masalah terkait perilaku seksual.

Pengertian perilaku seksual sering diasosiasikan semata-mata dengan terjadinya hubungan seksual antara seorang laki-laki dan perempuan yaitu terjadinya penetrasi vagina dan ejakulasi. Pengertian seperti ini terlalu simplisitik karena perilaku seksual mencakup segala bentuk ekspresi seksual yang dilakukan seseorang. Menurut Crooks (1983), perilaku seksual merupakan perilaku yang terdiri dari, berpelukan, berciuman, masturbasi/onani, petting, berhubungan intim (intercourse), lips kissing, deepkissing, genital stimulabon, petting, oral sex, anal sex dan sexual intercourse.

Penelitian pada negara berkembang menunjukkan bahwa 2-11\% wanita Asia telah melakukan hubungan seksual pada usia 18 tahun, 12-44\% wanita Amerika Latin pada usia 16 tahun dan 45-52\% dari wanita sub-Sahara Afrika melakukan pada usia 19. Sedangkan pada remaja laki-laki menunjukkan bahwa 24-75\% laki-laki Asia telah melakukan hubungan seks pada usia 18, 44-66\% laki-laki Amerika Latin pada usia 16 dan 45-73\% laki-laki sub-Sahara Afrika pada usia 17 (Brown, 2001). Di negara maju, sebagian besar perempuan muda telah melakukan hubungan seks sebelum usia 20, diantaranya di Perancis sebesar 67\%, Inggris sebesar 79\%, dan Amerika Serikat sebesar 71\% (Darroch, 2001) dan remaja laki-laki yaitu $83 \%$ di Perancis, $85 \%$ di Inggris dan $81 \%$ di Amerika Serikat (Darroch, 2001).

Minat mengenai seks pada masa remaja mengalami peningkatan sehingga mereka berusaha mencari lebih banyak informasi tersebut. Tingkah laku seksual remaja juga biasanya meningkat atau progresif. Sebuah tinjauan terhadap tingkah laku dan sikap seksual mahasiswa dari tahun 1900 ampai 1980 menunjukkan dua kecendrungan yang penting yaitu persentase orang muda yang mengatakan telah melakukan hubungan intim meningkat secara dramatis dan jumlah perempuan yang mengatakan telah melakukan hubungan seks meningkat jauh lebih cepat dari pada laki-laki (Santrock, 2003). Menurut Pangkahila (1998) telah terjadi perubahan pandangan dan perilaku seksual masyarakat, khususnya remaja. Hubungan ini tampak semakin muncul kepermukaan sejak satu dekade terakhir. Dimana terjadi pandangan dan perilaku seksual yang tampak dalam masa pacaran, menurutnya kini masa pacaran tidak lagi dianggap sebagai masa untuk saling mengenal atau memupuk saling pengertian, melainkan telah diartikan terlalu jauh sehingga seakanakan menjadi masa untuk "belajar melakukan aktivitas seksual dengan lawan jenis".

Penelitian yang dilakukan oleh Kushendiati (2005) di 4 Propinsi yaitu: Sumatera Selatan, Kalimantan Barat, NTT dan beberapa kabupaten di Jawa Barat dengan menganalisis data Survei Perilaku Berisiko yang Berdampak pada Kesehatan Reproduksi Remaja tahun 2002 yang dilakukan pada remaja yang berusia 15-24 tahun. Jumlah sampel yang digunakan oleh Meila sebanyak 2111 remaja (terdiri dari 1144 laki-laki dan 967 perempuan yg belum menikah). Dari hasil penelitian diperoleh perilaku seksual yang sering dilakukan adalah berpegangan tangan 64,9\%, berciuman 39\%, 
berpelukan/berangkulan 35,3\%, meraba daerah kelamin pacar 5,9\%, melakukan hubungan seksual $2,3 \%$.

Remaja sangat rentan terhadap penyakit terkait kesehatan reproduksi dan seksual karena mereka sering melakukan hubungan seks tidak aman (berganti pasangan dan tidak menggunakan kondom) dan sulit menemukan akses ke pelayanan kesehatan. Perilaku ini dapat menjadi media penularan penyakit kelamin seperti infeksi seksual menular seperti trikomoniasis, klamidia, sifilis atau gonore dan HIV/AIDS. Dampak lain dari perilaku seksual adalah kehamilan remaja. Menurut Finer (2006), sebagian besar kehamilan remaja di Amerika Serikat (82\%) merupakan kehamilan yang tidak diinginkan, dimana terdapat sekitar 40\% dari kehamilan yang tidak diinginkan pada remaja usia 15-19 berakhir dengan aborsi.

Salah satu faktor penting dalam perilaku seksual remaja adalah faktor keluarga. Peran keluarga sangat penting dalam proses perkembangan remaja. Keluarga terutama orang tua merupakan pendamping bagi remaja dalam menjalani masa perkembangan, dimana mereka hendaknya memberikan penjelasan perubahan yang dialami remaja serta pemahaman terhadap tugas perkembangan remaja serta melakukan pengawasan terhadap tindakan remaja. Keluarga juga merupakan tempat penanaman nilai-nilai moral dan keagamaan (Hurlock, 1998; Santrock, 2003).

Hubungan antara orang tua dan remaja juga akan mempengaruhi perilaku remaja dan akan dibawa terus ke titik lebih lanjut dalam perkembangan. Hubungan ini berfungsi sebagai contoh bagi remaja dalam membentuk hubungan baru dalam lingkungan sosial yang lebih luas (Santrock, 2003). Namun pada masa remaja, sering terjadi konflik dan perbedaan pendapat antara orang tua dan remaja. Hal ini disebabkan karena perubahan biologis, pubertas, perubahan kognitif (suka memberi kritik, jalan pikir egosentris,idealistik dan logis) perubahan sosial yang berpusat pada kebebasan dan jati diri serta pola emosi pada remaja cenderung tidak terkendali. Tapi di lain sisi, kebebasan yang bertambah yang mencirikan masa remaja dianggap pemberontakan oleh beberapa orang tua. Mereka melihat remaja mulai lepas dari pegangan mereka sehingga melakukan antisipasi dengan mengadakan pengendalian yang lebih ketat dan berharap remaja mereka memperhatikan nasihat mereka. (Santrock, 2003).

Pada sebuah penelitian didapatkan kondisi dimana remaja memiliki ibu yang mempunyai anak pada usia muda dan hidup di keluarga dengan pendapatan yang rendah, berkaitan dengan tingkah laku berhubungan seksual di usia muda (Crockett \& Bingham, 1994). Selain itu, keharmonisan keluarga mempunyai pengaruh terhadap perilaku remaja. Remaja yang mempunyai keluarga yang tidak harmonis seperti adanya perceraian lebih cenderung untuk merokok, alkohol, menggunakan narkoba dan melakukan hubungan seksual pada usia yang muda. Mereka juga mempunyai self concept, rasa percaya diri, kompetensi sosial dan kematangan yang berbeda dibandingkan dengan remja yang mempunyai keluarga utuh (Cobb, 2001). 
Komunikasi antara orang tua dan remaja mempunyai peran penting sebagai proteksi perilaku seksual berisiko. Orang tua memberikan informasi dan nilai penting yang kemudian berfungsi untuk melindungi remaja dari pengaruh teman sebaya. (Whitaker \& Miller, 2000). Namun, sebagian besar orang tua masih merasa tabu untuk membicarakan hal terkait dengan perkekmbangan seksual remaja sehingga banyak remaja yang mencari informasi melalui media cetak, media elektronik dan teman sebaya.

Penelitian yang dilakukan oleh Yeyen (2003) menunjukkan bahwa hanya 34,1\% responden yang menjadikan orang tua sumber informasi seksualitas. Proporsi ini lebih kecil dibandingkan dengan sumber lainnya, yaitu: dari teman sebesar 50\%, melalui media cetak sebesar 72,5\%, melalui media elektronik sebesar 53,8\% dan melalui sekolah sebesar $73,1 \%$. Pada penelitian ini juga didapatkan data bahwa sebagian besar reponden yaitu $75,3 \%$, menyatakan sulit berkominikasi dengan orang tua dengan alasan terbanyak orang tua/wali merasa tabu $(39,4 \%)$, responden merasa malu $(32,1 \%)$, responden merasa tidak perlu $(16 \%)$, orang tua/ wali sibuk $(0,5 \%)$ dan orang tua/wali tidak tahu mengenai topik seksualitas masing $(0,5 \%)$. Kesibukan orang tua dengan pekerjaannya mempengaruhi intensitas komunikasi dengan anknya (remaja) khususnya tentang pengetahuan seks. Hal ini menjadikan teman sebaya menjadi salah satu sumber penting dalam informasi remaja.

Teman sebaya memiliki beberapa fungsi seperti, kebersamaan dalam aktivitas, sumber informasi, pendorong fisik, pendorong ego, pendorong sosial dan kedekatan interaksi. Teman sebaya juga merupakan sumber afeksi, simpati dan pengertian, tempat untuk bereksperimen, dan suasana yang mendukung untuk mencapai otonomi dan kemandirian dari orang tua. Dari teman sebaya, remaja menerima umpan balik mengenai kemampuan mereka. Remaja belajar tentang apakah apa yang mereka lakukan lebih baik atau lebih buruk dari apa yang dilakukan remaja lain. Teman sebaya juga tempat untuk membentuk hubungan yang mendalam dengan orang lain. Maka tak heran jika remaja lebih suka menghabiskan waktu dengan teman sebayanya (Santrock, 2003).

Hubungan remaja dengan teman sebaya dapat berupa hal positif dan berupa hal negatif. Remaja menggali prinsip-prinsip kejujuran, keadilan, belajar menjadi teman yang memiliki kemampuan dan sensitif terhadap hubungan yang lebih akrab, serta belajar mengamati minat dan pandangan teman sebaya dengan tujuan untuk memudahkan proses penyatuan dirinya ke dalam aktivitas teman sebaya. Namun, teman sebaya juga dapat mengenalkan remaja dengan alkohol, obat-obatan dan kenakalan lainnya. (Santrock, 2003)

Pada sebagian remaja, bagaimana mereka dipandang oleh teman sebaya merupakan aspek yang terpenting dalam kehidupan mereka. Beberapa remaja akan melakukan apapun, agar dapat dimasukkan sebagai anggota, bahkan melakukan konformitas. Bagi mereka, dikucilkan berarti stres, frustasi dan kesedihan. Konformitas muncul ketika individu meniru sikap atau tingkah laku orang lain disebabkan tekanan sosial. Hal ini dapat diamati pada hampir setiap sisi kehidupan remaja, seperti pilihan remaja mengenai baju yang ingin dipakai, musik yang ingin didengarkan, bahasa, nilai-nilai dan lainnya. Orang tua dapat membantu remaja untuk mengahadapi tekanan dari teman sebaya, karena dengan adanya 
konformitas dapat merusak nilai-nilai yang telah ditanamkan dalam keluarga (Santrock, 2003).

Teman sebaya juga merupakan sumber informasi mengenai dunia di luar keluarga. Informasi yang didapatkan dari teman sebaya dapat berupa pengetahuan, nilai yang dianut serta pandangan mengenai suatu hal (Santrock, 2003). Remaja menginginkan teman yang mempunyai minat dan nilai-nilai yang sama, yang dapat mengerti dan membuatnya marasa aman, dan kepada mereka remaja dapat mempercayakan masalah-masalah dan membahas hal-hal yang tidak dapat dibicarakan dengan orang tua. (Hurlock, 1998).

Kuatnya pengaruh teman sebaya dalam kelompok dapat menanamkan nilai-nilai kelompok pada setiap anggotanya. Itulah sebabnya, pada banyak kasus, penyimpangan perilaku seksual, remaja banyak diilhami dari pengalaman, bujukan atau cerita teman kelompok sebayanya. Banyak remaja mendapatkan informasi mengenai seksualitas dari temannya dan banyak dari mereka yang mendapatkan informasi yang salah (Cobb, 2001). Menurut Santrock (2003), remaja laki-laki merasakan tekanan dari teman sebayanya untuk melakukan hubungan seks dan untuk menjadi aktif secara seksual. Remaja yang sangat tergantung pada teman-teman sebayanya dan tidak banyak terlibat dengan keluarganya, cenderung lebih memiliki keterlibatan seksual, dimana ketergantungan remaja laki-laki terhadap teman sebayanya merupakan faktor yang kuat untuk meramalkan aktivitas seksual mereka. (Jessor, dkk., 1983).

\section{METODE PENELITIAN}

Penelitian ini bersifat deskriptif menggunakan desain penelitian cross sectional, yaitu pengamatan terhadap variabel independen dan dependen dilakukan pada waktu yang sama. Tempat penelitian dilakukan di Fakultas X Kampus Universitas Indonesia Depok. Pengambilan data dilaksanakan pada bulan April 2012 dengan jumlah 124 orang. Data yang dikumpulkan merupakan data primer. Instrumen yang digunakan dalam penelitian ini adalah kuesioner berisi pertanyaan tertutup dan daftar cocok (checklist) yang akan diisi sendiri oleh responden (self-administered). Teknik analisis data menggunakan teknik analisis deskriptif dan bivariat. Analisis bivariat melihat hubungan antara keluarga dan teman sebaya dengan perilaku seksual remaja dengan menggunakan uji Chi-Square.

\section{HASIL DAN PEMBAHASAN \\ Perilaku Seksual Remaja}

Tahapan perilaku seksual dalam penelitian ini terdiri dari 13 tahapan yaitu ngobrol, nonton, jalan berdua, berpegangan tangan, berpelukan, berciuman pipi, berciuman bibir/ leher, meraba/ meremas payudara, meraba daerah sensitif/alat kelamin, saling menempelkan alat kelamin (petting) dengan dibatasi pakaian dan tanpa dibatasi pakaian, mengulum alat kelamin pasangan (oral sex), berhubungan seksual (sexual intercourse). Berdasarkan hasil analisis data, diperoleh sebesar 95,2 \% (118 orang) responden melakukan tahapan pertama yaitu ngobrol dan sebesar 78,2\% (97 orang) melakukan 
tahapan kedua, yaitu nonton. Sementara kegiatan jalan berdua sebesar 85,5\% ( 106 orang). Pada analisis selanjutnya, tahapan-tahapan ini akan dikelompokkan menjadi perilaku seksual tidak berisiko.

Persentase responden yang berpegangan tangan adalah sebesar 70,2\% (87 orang), berpelukan sebesar 52,4\% (65 orang). Pegangan tangan dan/ atau berpelukan merupakan tahap pertama dari perilaku seksual. Pegangan tangan atau berpelukan akan menimbulkan perasaan nyaman dan dapat menimbulkan rangsangan erotis walaupun pada awalnya kegiatan ini dilakukan dengan maksud untuk menunjukkan perasaan sayang. Rangsangan erotis yang timbul tersebut dapat membawa seseorang untuk melakukan tahapan-tahapan perilaku seksual berikutnya, seperti kissing, petting dan sexual intercourse.

Hal ini dapat terlihat, dimana dari tahapan sebelumnya, remaja melakukan tahapan lebih lanjut yaitu berciuman, yang terdiri dari berciuman pipi sebesar $41,9 \%$ (52 orang) dan berciuman bibir/ leher sebesar 26,6\% ( 33 orang) walaupun persentasenya lebih sedikit dibandingkan dengan pegangan tangan dan berpelukan. Berciuman bibir merupakan bagain dari keintiman. Maka, tidak mengherankan banyak remaja yang melakukannya dengan pasangannya. Apalagi stimulus untuk melakukannya beredar dimana-mana. Kini untuk dapat melihat adegan ciuman bibir, remaja tidak harus melihatnya di VCD porno karena saat ini adegan tersebut tidak lagi semubunyi-sembunyi ditayangkan. Contohnya, di bioskop atau VCD film-film yang biasa beredar untuk umum, dimana adegan ciuman bibir dapat kita temui dengan mudah.

Akibat rangsangan erotis dari berciuman, remaja akan lanjut pada tahapan berikutnya yaitu menyentuh bagian sensitif dari tubuh pasangan. Dari analisis terdapat sebesar 8,9\% (11 orang) remaja yang meraba/ meremas payudara dan meraba daerah sensitif/alat kelamin sebesar 4\% (5 orang). Sedangkan kegiatan menempelkan alat kelamin (petting) dengan dibatasi pakaian dan tanpa dibatasi pakaian mempunyai proporsi yang sama yaitu 1,6\% (2 orang). Pada tahapan ini, telihat persentase remaja yang melakukannya semakin sedikit. Tahapan menyentuh bagian sensitif dan petting ini sangat berisiko sebab walaupun remaja belum melakukan hubungan seksual, seseorang yang melakukan petting dapat dengan mudah kehilangan kotrol diri. Seseorang yang melakukan petting akan lebih mudah untuk melakukan hubungan seksual. Hal ini dapat terlihat, bahwa terdapat satu orang $(0,8 \%)$ yang melakukan hubungan seksual dan dan oral sex. Dari 124 responden, diketahui bahwa sebagian besar melakukan kegiatan ngobrol, nonton, jalan berdua dan berpegangan tangan. Sedangkan proporsi terkecil dari perilaku seksual yang dilakukan responden adalah kegiatan oral sex dan sexual intercourse.

Kemudian, tahapan perilaku seksual dibagi menjadi 2 kategori, yaitu perilaku tidak berisiko dan perilaku seksual berisiko. Perilaku tidak berisiko adalah perilaku dimana responden tidak pernah mempunyai pacar/ pasangan atau punya pacar tetapi hanya melakukan kegiatan ngobrol, nonton dan jalan-jalan berpegangan tangan. Sementara perilaku seksual berisiko terdiri dari berpelukan, mencium pipi dan mencium leher, mencium bibir, memegang payudara, memegang alat kelamin, petting dengan dibatasi pakaian, petting tanpa dibatasi pakaian, oral seks dan hubungan seksual (Crooks,1983; 
Kollman, 1998). Berdasarkan hasil analisis, didapatkan bahwa sebagian besar mahasiswa memiliki perilaku seksual berisiko yaitu sebesar 53,2\% (66 responden). Sementara mahasiswa yang mempunyai perilaku seksual tidak berisiko adalah 46,8\% (58responden).

\section{Faktor Keluarga}

Komunikasi antara orang tua dan remaja mempunyai peran penting sebagai proteksi perilaku seksual berisiko. Orang tua memberikan informasi dan nilai penting yang kemudian berfungsi untuk melindungi remaja dari pengaruh teman sebaya. (Whitaker \& Miller, 2000). Penelitian yang dilakukan oleh Clawson, et. al. (2003), menunjukkan bahwa terdapat hubungan antara komunikasi perilaku seksual dengan perilaku seksual. Orang tua hendaknya mulai berdiskusi mengenai kesehatan reproduksi dan perilaku seksual di awal perkembangan remaja karena pada penelitian ini waktu mulai berdiskusi dengan remaja memberi kontribusi dalam memprediksi umur saat melakukan hubungan seksual pertama kali, jumlah pasangan dan kehamilan.

Kualitas komunikasi secara keseluruhan (tidak hanya spesifik pada kesehatan reproduksi dan seksual) dan kualitas hubungan orang tua dan remaja juga merupakan faktor penting. Penelitian yang dilakukan oleh Miller (1999) menunjukkan bahwa komunikasi umum juga penting, komunikasi antara ibu dan remaja berhubungan dengan jumlah pasangan seksual yang lebih sedikit dan jarang berhubungan intim (Miller et al, 1999).

Menurut Deptula (2010), faktor orang tua seperti kualitas hubungan orangtua-remaja berfungsi sebagai faktor promotif yang dapat mengurangi keterlibatan awal dalam perilaku seksual berisiko. Komunikasi dapat membentuk hubungan baik dengan orang tua. Orang tua hendaknya dapat memberikan kenyamanan ketika berbicara mengenai seksual sehingga remaja menjadi percaya dan terbuka dalam membahas masalah kesehatan reproduksi terutama perilaku seksual (Deptula, 2010). Hasil yang sama juga diperoleh oleh Whitaker et. al. (2000) dan Victa (2006). Pada penelitian ini di temukan bahwa komunikasi orang tua-remaja mempunyai hubungan yang bermakna dengan perilaku seksual berisiko.

Berdasarkan hasil analisis menunjukkan hasil dimana porporsi terbesar yang melakukan perilaku seksual adalah remaja yang berkomunikasi dengan orang tua yaitu sebesar $66,7 \%$. Sementara responden yang tidak berkomunikasi dengan keluarga mengenai kesehatan reproduksi dan seksual melakukan perilaku seksual berisiko sebesar 48,9\%. Hasil uji statistik menunjukkan tidak ada hubungan signifikan antara perilaku seksual dengan komunikasi kesehatan reproduksi dengan orang tua (nilai p 0,138). Hal ini berarti bahwa tidak ada perbedaan proporsi perilaku seksual pada remaja yang yang berkomunikasi dengan orang tua dan tidak berkomunikasi dengan keluarga. Walaupun terdapat komunikasi mengenai kesehatan antara remaja dan orang tua, tetapi ada kemungkinan topik yang dibicarakan hanya pada topik-topik tertentu. Hal ini disebabkan karena banyak orang tua yang menganggap tabu untuk membicarakan keseluruhan. Selain itu, ketika orang tua menyampaikan masalah seksualitas pada remaja, ada anggapan bagi orang tua, hal ini akan menyebabkan remaja untuk mencoba atau melakukan perilaku 
seksual itu sendiri. Oleh karena itu banyak orang tua yang tidak memberikan informasi atau pendidikan seks kepada remaja.

Selain itu faktor dukungan keluarga juga sangat penting. Dukungan keluarga yang positif berhubungan dengan kedekatan hubungan antara orang tua dan remaja, rasa harga diri yang tinggi, kesuksesan akademik, dan perkembangan moral yang lebih baik. Kekurangan dukungan dari keluarga dapat memberikan dampak yang berlawanan, yaitu harga diri yang rendah, egois dalam berperilaku, sulit menyesuaikan diri dengan lingkungan sosial, berperilaku menyimpang (deviant) dan anti sosial ( Rice, 1996).

Pada penelitian yang dilakukan oleh Deptula (2010) diperoleh bahwa hubungan orang tua dengan remaja merupakan faktor penting yang berhubungan dengan perilaku seksual berisiko remaja. Hubungan orang tua dengan remaja yang berkualitas tinggi berhubungan dampak kesehatan seksual remaja yang lebih baik (contohnya, diagnosis IMS yang lebih rendah) (Deptula, 2010). Hasil yang sama juga diperoleh oleh Whitaker et. al. (2000), dimana kedekatan hubungan orang tua-remaja mempunyai hubungan yang bermakna dengan perilaku seksual berisiko.

Berdasarkan hasil analisis hubungan dukungan keluarga dengan perilaku seksual didapatkan bahwa persentase terbesar dalam melakukan perilaku seksual adalah remaja dengan dukungan keluarga rendah (60,6\%). Sedangkan persentase remaja dengan dukungan keluarga tinggi yang melakukan perilaku seksual berisiko adalah sebesar 50,7\% dan remaja dengan dukungan keluarga sedang sebesar 50\%. Hasil uji statistik memperlihatkan tidak adanya hubungan antara perilaku seksual dengan dukungan keluarga, dimana niali $\mathrm{p}>0,05$. Hal ini disebabkan karena, pada masa remaja, perilaku lebih banyak dipengaruhi oleh teman sebaya. Budaya teman sebaya dapat mempengaruhi remaja untuk menyepelekan nilai-nilai dan kendali orang tua terhadap mereka. Hal ini juga didukung dengan tempat tinggal yang terpisah dari orang tua. Sehingga remaja menjadi lebih bebas dan tidak dapat diawasi sepenuhnya.

\section{Faktor Teman Sebaya}

Berdasarkan hasil analisis diperoleh persentase lebih besar pada remaja dengan pengaruh negatif teman sebaya yang besar terhadap perilaku seksual berisiko yaitu sebesar $78,7 \%$. Sedangkan remaja dengan pengaruh teman sebaya yang kecil melakukan perilaku seksual berisiko sebesar 54\%. Hasil uji statistik menunjukkan nilai signifikan atau lebih kecil dari 0,05 ( nilai p sebesar 0,007) sehingga terdapat perbedaan proporsi perilaku seksual pada remaja dengan pengaruh teman sebaya yang kecil dan pengaruh negatif teman sebaya yang besar. Responden dengan pengaruh teman sebaya besar lebih berisiko melakukan perilaku seksual sebesar 3,149 kali dibandingkan dengan responden pengaruh teman sebaya yang kecil.

Remaja cendrung terpengaruh sikap teman-temannya, contohnya dalam pilihan musik, fashion dan seks. Remaja sering berpikir apakah perilaku mereka sesuai dengan pendapat dan tindakan teman-temannya. Remaja yang memiliki teman yang aktif secara seksual dan setuju terhadap perilaku seksual pranikah cendrung untuk melakukan perilaku 
seksual (Marín, Coyle, Gomez, Carvajal, \& Kirby, 2000 dalam Driscoll, 2001). Hasil yang sama juga diperoleh oleh Kirby (2002) dimana perilaku teman sebaya dan kepuasan mereka dalam melakukan hubungan seks pranikah yang tidak aman merupakan faktor penting yang mempengaruhi inisiasi seksual dini (Kirby, 2002 dalam Joshi, 2011). Penelitian yang dilakukan Lanova Dwi Arde (2011) menunjukan bahwa 53,4\% remaja mempunyai teman yang pernah melakukan hubungan seksual dan $26 \%$ terdorong untuk melakukan hubungan seks. Remaja dengan pengaruh teman sebaya yang besar lebih banyak melakukan perilaku seksual berisko $(72,8 \%)$ dibandingkan pengaruh teman yang kecil $(33,5 \%)$ sehingga mereka berisiko melakukan perilaku seksual berisiko 6 kali lebih besar.

Teman sebaya juga merupakan sumber informasi mengenai dunia di luar keluarga. Informasi yang didapatkan dari teman sebaya dapat berupa pengetahuan, nilai yang dianut serta pandangan mengenai suatu hal. Kuatnya pengaruh teman sebaya dalam kelompok dapat menanamkan nilai-nilai kelompok pada setiap anggotanya. Itulah sebabnya, pada banyak kasus, penyimpangan perilaku seksual, remaja banyak diilhami dari pengalaman, bujukan atau cerita teman kelompok sebayanya. Banyak remaja mendapatkan informasi mengenai seksualitas dari temannya dan banyak dari mereka yang mendapatkan informasi yang salah. Remaja yang sangat tergantung pada teman-teman sebayanya dan tidak banyak terlibat dengan keluarganya, cenderung lebih memiliki keterlibatan seksual, dimana ketergantungan remaja laki-laki terhadap teman sebayanya merupakan faktor yang kuat untuk meramalkan aktivitas seksual mereka.

Pengaruh teman sebaya dapat diminimalisir dengan adanya komunikasi dan dukungan dari keluarga remaja. Pada dukungan keluarga tinggi diperoleh persentase melakukan perilaku seksual lebih besar pada remaja dengan pengaruh teman besar $(66,7 \%)$ dibandingkan remaja dengan pengaruh teman kecil $(34,8 \%)$. Sedangkan pada dukungan keluarga rendah, remaja dengan pengaruh teman besar, lebih banyak $(81,3 \%)$ melakukan perilaku seksual berisiko dibandingkan dengan remaja dengan pengaruh teman kecil $(41,2 \%)$. Secara statistik terdapat hubungan bermakna antara pengaruh teman sebaya dengan perilaku seksual, baik pada dukungan keluarga tinggi maupun rendah.

Hasil analisis hubungan antara pengaruh teman sebaya dengan perilaku seksual didapatkan bahwa mahasiswa dengan pengaruh teman sebaya besar lebih berisiko melakukan perilaku seksual sebesar 4,155 kali dibandingkan dengan mahasiswa pengaruh teman sebaya yang kecil. Namun, setelah distratifikasi dengan dukungan keluarga diperoleh hasi bahwa mahasiswa dengan dukungan keluarga tinggi dan pengaruh teman besar berisiko lebih kecil (3,7 kali) untuk melakukan perilaku seksual berisiko dibandingkan dengan pengaruh teman kecil. Sedangkan mahasiswa dengan dukungan keluarga rendah dan pengaruh teman besar berisiko lebih besar (6,2 kali) untuk melakukan perilaku seksual berisiko dibandingkan dengan pengaruh teman kecil. 


\section{SIMPULAN}

Berdasarkan hasil penelitian diperoleh persentase remaja yang memiliki perilaku seksual berisiko sebesar 66,1\% dan pengaruh teman sebaya besar sebesar 49,2\%. Sebagian besar remaja memperoleh dukungan keluarga besar $(60,5 \%)$ dan sebagian besar tidak melakukan komunikasi $(75,8 \%)$. Hasil uji hipotesis diperoleh remaja dengan pengaruh negatif teman sebaya yang besar lebih banyak melakukan perilaku seksual berisiko (70,5\%) dibandingkan dengan pengaruh kecil (36,5\%) dengan nilai PR 4,2 dimana remaja dengan pengaruh teman sebaya yang besar berisiko melakukan perilaku sesksual sebesar 4,2 kali.

Hasil analisis hubungan pengaruh teman sebaya dan perilaku seksual menurut dukungan keluarga diperoleh pada dukungan keluarga tinggi diperoleh persentase responden dengan pengaruh teman besar, lebih banyak (66,7\%) melakukan perilaku seksual berisiko dibandingkan dengan responden dengan pengaruh teman kecil $(34,8 \%)$. Sedangkan pada dukungan keluarga rendah, responden dengan pengaruh teman besar, lebih banyak (81,3\%) melakukan perilaku seksual berisiko dibandingkan dengan responden dengan pengaruh teman kecil $(41,2 \%)$. Secara statistik terdapat hubungan bermakna antara pengaruh teman sebaya dengan perilaku seksual, baik pada dukungan keluarga tinggi maupun rendah.

\section{DAFTAR PUSTAKA}

Arde, Lanova Dwi. (2011). Hubungan Pengetahuan, Sikap, dan Lingkungan Sosial terhadap Perilaku Seksual Remaja di Indonesia tahun 2007. Skripsi. Depok. FKM UI.

Brown AD et al. (2001). Sexual Relations among Young People in Developing Countries: Evidence from WHO Case Studies. Geneva: World Health Organization, http://whqlibdoc.who.int/hq/2001/WHO_RHR_01.8.pdf

Clawson, Carolyn L. Dan Marla Reese-Weber. (2003). The Amount and timing of ParentAdolescent Sexual Communication as Predictor of Late Adolescent Sexual RiskTaking Behaviors. The Journal of Sex Research Vol.40 No.3: 256-265.

Cobb, Nancy J. (2001). Adolescence: Continuity, Change and Diversity (4th ed.). California: Mayfield Publishing Company.

Crooks, Robert dan Karla Baur. (1983). Our Sexuality (2th ed.). California: The Bejamin/ Cumming Publishing Company Inc.

Darroch JE et al. Differences in teenage pregnancy rates among five developed countries: the role of sexual activity and contraceptive use. Fam Plann Perspectives 2001; 33:244-50. 
Deptula, Daneen P., David B. Henry dan Michael E. Schoeny. (2010). How Can Parents Make a Difference? Longitudinal Associations With Adolescent Sexual Behavior. Journal of Family Psychology 2010, Vol. 24, No. 6, 731-739.

Driscoll, Anne K., M. Antonia Biggs, Claire D. Brindis and Ekua Yankah. (2001). Adolescent Latino Reproductive Health: A Review of the Literature. Hispanic $\begin{array}{lllll}\text { Journal of } & \text { Behavioral } & \text { Sciences } & 2001 ; & 23 ;\end{array}$ http://hjb.sagepub.com/cgi/content/abstract/23/3/255

Finer, LB, \& Henshaw, S. (2006). Disparities in rates of unintended pregnancy in the United States. Perspectives on Sexual and Reproductive Health, 38(2), 90- 96. diunduh dari http://www.jstor.org/stable/4147929

Hurlock, Elizabeth B. (1998). Psikologi Perkembangan : Suatu Pendekatan Sepanjang Rentang Kehidupan ed.5 (Istiwidayanti dan Soedjarwo, Penerjemah). Jakarta: Erlangga.

Joshi, Beena dan Sanjay Chauhan. (2011). Determinants of Youth Sexual Behaviour: Program Implications for India. Eastern Journal of Medicine 16, p.113-121. www.easternjmed.org/PDF/2011_2/113.pdf

Kollmann, Nathalie. (1998). Kesehatan Reproduksi Remaja : Program Seri Lokakarya Kesehatan Perempuan. Jakarta : YLKI dan The Ford Foundation.

Pangkahila, A. (2004). Perilku Seksual Remaja dalam Tumbuh Kembang Remaja dan Permasalahannya. Jakarta: Cv.Sagung Seto.

Kushendiati, Meila. (2005). Hubungan Karakteristik Remaja, Pornografi dan Sumber Informasi dengan Perilaku seksual Remaja Di Empat Provinsi di Indonesia (Analisis Survei Perilaku Berisiko yang Berdampak pada Kesehatan Reproduksi Remaja 2002). Skripsi. Depok. FKM UI.

Miller, K. S., Forehand, R., \& Kotchick, B. A. (1999). Adolescent sexual behavior in two ethnic minority samples: The role of family variables. Journal of Marriage and Family, 61, 85-98.

Pangkahila, Wimpie. (1998). Seksualitas Anak dan Remaja. Jakarta: Gramedia.

Santrock, John W. (2003). Adolescence : Perkembangan Remaja (Shinto B. Adelar dan Sherly Saragih, Penerjemah). Jakarta: Erlangga.

Victa. (2006). Faktor-Faktor yang Berhubungan dengan Kegiatan Seksual Mahasiswa Universitas Indonesia Tahun 2006. Skripsi. Depok. FKM UI. 
188 | Sari - Keluarga, Teman Sebaya ...

Whitaker, D. J., \& Miller, K. S. (2000). Parent-adolescent discussions about sex and condoms: Impact on peer influences of sexual risk behavior. Journal of Adolescent Research, 15, 251-273. 